Article

\title{
Population, Resources and Female Labor in the Raw Silk Industry of Nagano in Meiji Japan
}

\author{
Tim F. Liao \\ Department of Sociology, University of Illinois at Urbana-Champaign, Urbana, IL 61801, USA; \\ E-Mail: tfliao@illinois.edu; Tel.: +1-217-333-7988
}

Received: 3 December 2012; in revised form: 28 February 2013 / Accepted: 1 March 2013 /

Published: 7 March 2013

\begin{abstract}
Gendered realities in local regions are a prominent issue in today's global economy. However, the process of globalization in the late-19th century already involved the local Nagano women in an indispensable role in Japan's raw silk industry. This paper studies the interplay between population growth and relatively limited resources in Nagano vis-à-vis the demand for female labor during the Meiji era, when Japan became a major raw silk producer. The local/regional constraints in Nagano interacted with economic globalization and gave Nagano its position in the global market. Therefore, we cannot ignore the consequences of local/regional constraints and advantages in global processes on female workers. Population pressure and environmental squeeze are found to have been important forces that integrated the local and regional in the global process of industrialization and trade, and together, they produced social outcomes, such as gender hierarchies in globalization and glocalization processes.
\end{abstract}

Keywords: regional reality; population; globalization; Meiji Era; Nagano; raw silk industry

\section{Introduction}

The global economy, made ubiquitous by multinational corporations in the latter half of the 20th century, created severe consequences of gender inequality. Research on women's role in the global economy has shown that economic development and policies to encourage such development often led to further marginalization of women's status [1-5]. However, the interaction between globalization and gender equity has its historical regional roots and precedents. The late 19th century saw continued expansion of the Western economic powers in the wake of industrialization. The expansion of the capitalist market and the demand for raw materials integrated nonwestern societies into the global 
economy to an unprecedented scale - with important gender ramifications for the supplying regions of raw materials located in the regions outside the strongholds of the world's capitalist powers.

In this paper, I study a representative producer of a particular raw material in a non-Western society in this global economy - the raw silk industry in Japan - from late 19th to early 20th century, when Japan became the number one raw silk producer in the world. A century later, the global division of labor of raw silk production is rather different. In the year 2000, Japan occupied the eighth place in raw silk production, after China, India, Brazil, Uzbekistan, Vietnam, Thailand and Iran, with its total output less than one-percent of China's and less than two-thirds of Iran's [6]. Around the turn of the twentieth century, together with cotton spinning and weaving, silk production employed most of the women workers outside agriculture in Japan. Women's contribution to the raw silk industry and to Japan's economic development during this historical period can never be overestimated. In fact, the female labor force in the silk and cotton industries produced so much profit that it helped make the "Meiji Miracle" [7]. The focus of the paper is on a major raw silk producing region in Japan in the Meiji Era (1868-1912), Nagano Prefecture', and on Nagano's female labor in the raw silk industry during this period.

Of the prefectures in Japan, why did Nagano become the paramount producer of raw silk? Landlocked and mountainous, Nagano might not be an obvious choice as a hub of silk production, as it turned out to be without direct access to ports for shipping silk to overseas location. Furthermore, traditionally relying on farming for subsistence, why would Nagano peasants want to contract their daughters off to the factories in spite of the supply of migrant labor from neighboring prefectures? To better understand Nagano's rise as the major silk reeling region in Japan and the employment of many of its young women in harsh work conditions, I examine Japan's as well as Nagano's population trends and the prefecture's ecological resources. Although there is a relatively large body of literature on the Japanese raw silk industry of the time and how it related to the world and a sizable amount of literature on the workers in such industry (e.g., [5,8-12]), the focus of the current research is on how the national and local demographic and environmental forces gave rise to the silk industry, thereby conditioning women's participation in the globalization of silk reeling.

The demographic and ecological conditions in Nagano were the local realities that interacted with the global economic market, in a process known as glocalization. Even though the discourse has been formed in the last few decades, local, national and regional entities around the world have been gradually integrated into the world system over the last few centuries, and the integration has intensified for more than a century or so. This integration of the local into the global involved several processes - namely, cultural, communication, economic and political globalization in Chase-Dunn's typology [13]. Among these sometimes parallel processes, economic globalization is believed to precede cultural and political globalization [13].

Nagano involved itself in the process of economic globalization since the 19th century with its active role in raw silk production. It can be said that the demographic and ecological pressures in Meiji Nagano made it an ideal location for the raw silk industry. As shown in the analysis below, higher than average population growth guaranteed enough surplus labor, and the relative scarcity of prime farmland funneled this surplus labor elsewhere (i.e., away from agriculture). To anticipate the

1 In the early Meiji Era, Nagano Prefecture was known as Shinano, which administratively covered an identical geographical area as Nagano Prefecture later did. 
conclusion, the need for income, the disadvantage of women in farm work and the stereotypical advantage of female dexterity, both pushed and pulled them into silk reeling, into long hours and monotonous work but sure meals and into possible harassment by their foremen.

In the next section, I review the history of the Japanese raw silk industry and Nagano's position in the industry. This is followed by a discussion of Nagano's female labor force in the industry. To understand why Nagano and its women became Japan's major raw silk producer, I explore the demographic forces in Meiji Japan. I then examine the ecological pressure in Nagano. Finally, I discuss the twin processes of global economy and gender in light of the demographic and ecological forces by examining the local and global interaction that typically follows the initial mediation of the national. Therefore, the historical case study of female labor force in the Meiji silk-reeling industry does not just tell an interesting story about early working women, a story that has been told by many others. What is more important for contemporary social science scholarship is that the case reflects modern concerns with labor, gender roles and globalization. As the reader will find out later in the paper, the local contexts of Nagano in terms of the pressure of population increase and the squeeze of the agricultural environment as well as the local advantages of hand-reeling tradition collaborated with economic globalization to produce an overwhelmingly female labor force in Nagano's raw silk industry. The combined forces resulted in a glocalization process: a process that reallocated poverty and stigma [14].

The theoretical approach to analyzing Nagano's female labor force in Japan's raw silk industry during the Meiji period is consistent with the recent scholarship on the importance of tradition in Japan's modernization in the mode of dual economy [15-18]. This scholarship made a significant contribution to understanding Japan's economic development, previously often perceived as shaped by the imported Western industry only. The emphasis of this recent body of research is on the role of the “indigenous development" in Japan's industrialization [16]. Indeed, such indigenous development formed part of the local forces in shaping the larger process of glocalization through which Western machinery and knowledge as well as local productive forces and local demographic and environmental characteristics together moved Nagano and Japan along the path of industrialization. The current paper contributes to the existing literature by studying and analyzing both the global and the local forcesespecially Nagano's demographic and environmental conditions - that helped shape the larger process of glocalization in which Japan's raw silk industry was situated.

\section{Japan and the Global Silk Trade from Late 19th to Early 20th Century}

Marco Polo may have been popularly credited for bringing fine silk back to Europe. The demand for raw silk, which could be processed into silk textile, was actually higher than ever in the 19th century. Traditional European producers of raw silk, such as France and Italy, could only supply a portion for meeting the demand that inevitably required the silk textile makers to go elsewhere. Both Japan and China produced inexpensive raw silk, though up to the mid-19th century, the major producer of raw silk had been France, with the price of Japanese raw silk being only about half as much as the French counterpart's. The Meiji Restoration in 1868 opened Japan's ports to the world. With that, raw silk quickly became Japan's most important export.

However, to increase the volume of production meant a need to modernize the production method. Because modernization was the spirit of the Meiji reform, changing from using a sedentary reeling 
machine (zakuri-ki) inherited from the Edo era (1600-1867) to the Western, filature method came naturally. The discussion of the two production methods below follows Togo's [19].

Raw silk was used in two ways in making textile, as warp (the set of yarns set lengthwise in the loom) and as woof (yarn carried by shuttle, interlacing with warp). Apparently, the warp must be of stronger material if the two could be of different quality. Applying the sedentary method, a reeler would use her right hand to rotate a spool and her left to connect and throw threads. Raw silk produced by this method typically was used as the woof for making silk textile in the West.

The basic difference between the traditional sedentary reeling method (zakuri-seishi) and the Western filature method (kikai-seishi) is that, unlike the former that required use of both hands, the latter used a mechanical power source to rotate the spools. The reeler could thereby free up her right hand as well to reel the raw silk. Throwing threads was also done by mechanical power. The filature method was appropriate for manufacturing a large quantity of raw silk of similar quality.

The Meiji government promptly realized the necessity to improve the quality of Japanese raw silk. The government implemented a series of policies, and the best known was to establish modern Western-style filature plants as pilot factories for modern raw silk production. The most famous filature plant was the Tomioka Filature Plant in Gunma Prefecture, established in 1872. In 1870, the government invited Paul Brunat, a French engineer, who subsequently imported French machines that called for 100 reelers. He and four French female reelers came to teach the Japanese. In addition to the French, the Italians were also involved in the introduction of modern Western silk reeling technology to Japan. Therefore, the Japanese could produce a medium quality of raw silk suited for use as either the warp or the woof. Raw silk of such quality could satisfy the general demand for a large quantity. Thus, Japan's raw silk production became firmly integrated in the global silk trade in a triangular relationship during the Meiji Era, as illustrated in Figure 1.

Figure 1. Japan in the Global Silk Trade, 1870-1912.

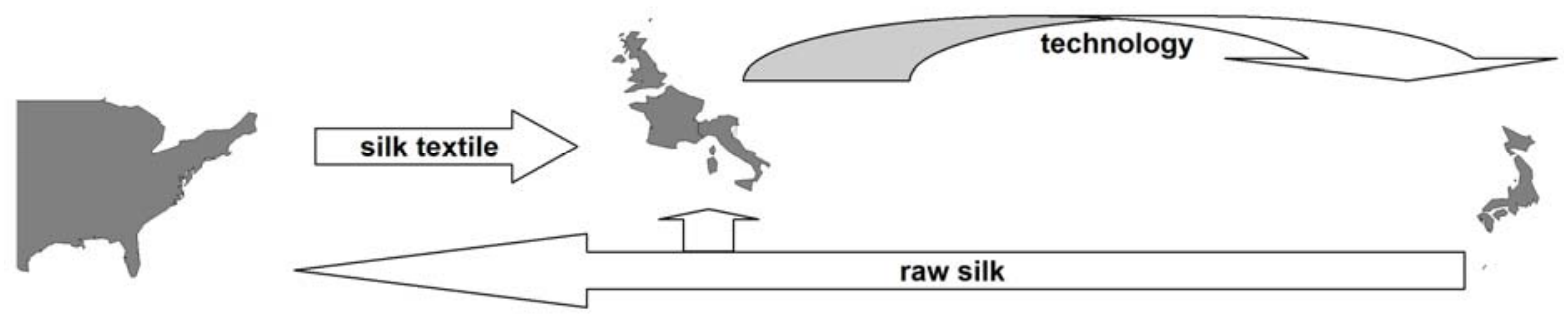

France and Italy were major suppliers of raw silk reeling machinery to Japan, beginning from 1870 . Japan relied on local silkworms for cocoons for making raw silk, and it exported raw silk to Europe (chiefly France and Great Britain) and especially the United States, since France's economic crisis in 1882 [20]. Britain's import of Japanese raw silk decreased to an insignificant level in the second half of the Meiji Era, with the United States becoming Japan's major raw silk purchaser for use in its textile industry, mostly located in New England. By 1909, the United States solidly established itself as the major supplier of silk textile to the world.

Also during the same period, Japan established itself as the primary raw silk supplier in the world. As early as 1882, Japanese raw silk export to the US market exceeded its Chinese counterpart, 
However, it was not until later that Japan surpassed China in total raw silk production (Figure 2, data taken from [19] based on [21]).

Figure 2. Raw Silk Production in the World, 1905-1911.

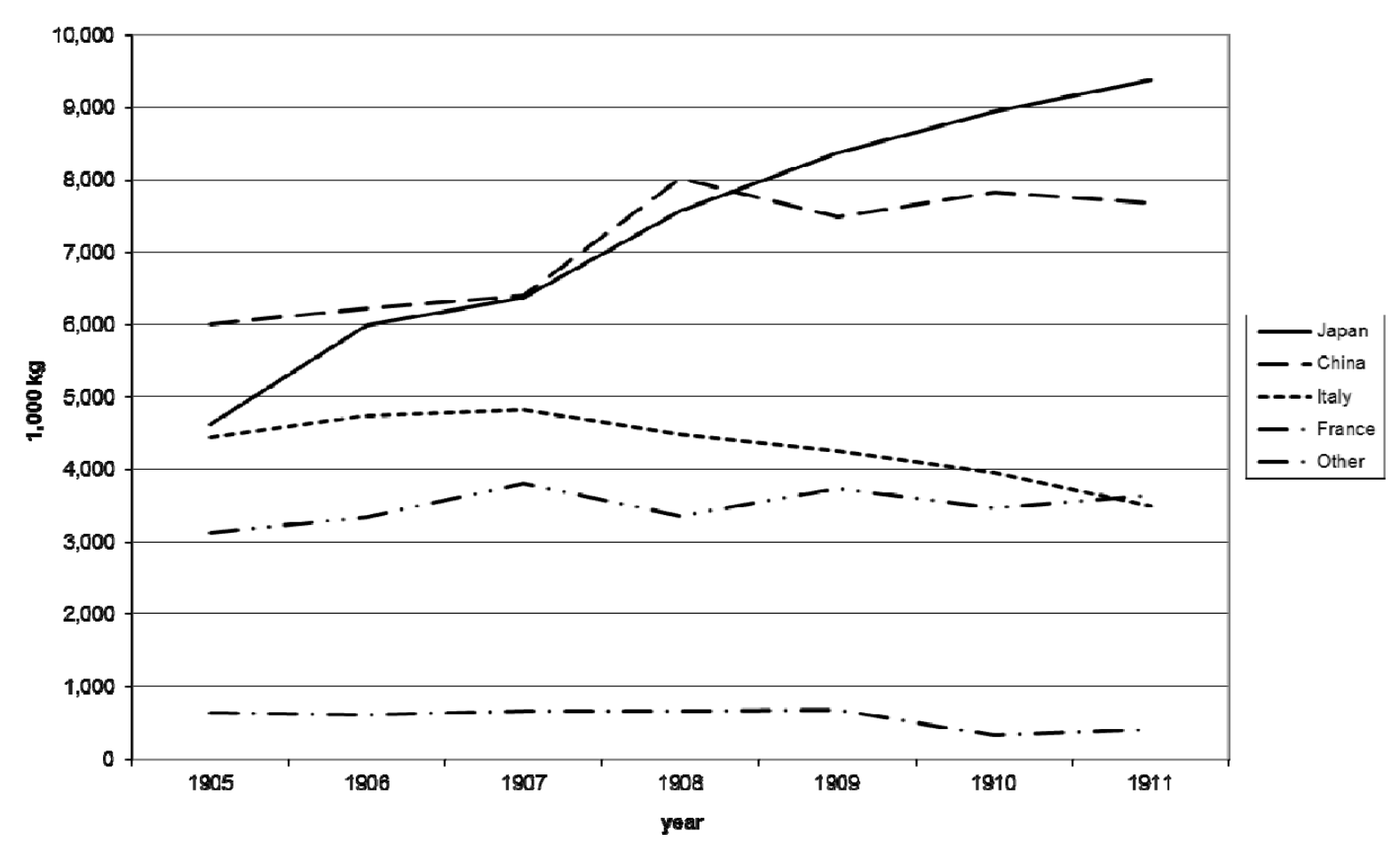

Figure 2 presents the total production amounts of major silk producers in early 20th century. Clearly, China, Japan and Italy dominated raw silk production, especially since the data for China and Japan are export amounts only, while the corresponding data are total amounts for the other countries. Japan's impact on the silk market was tremendous, particularly because its raw silk was of a higher quality than its Chinese counterpart.

The integration of Japan into the global silk trade also reflects the country's participation in the larger process of trade globalization, because the silk market was an important integral part of the global trade. In the late 19th and the early 20th century, there were two cycles of trade globalization, measureable by the average openness of global trade, as identified by Chase-Dunn, Kawano and Brewer [22]. The rise in trade globalization between 1850 and the late 1880s and again during the 1900s and 1910s coincided with the world's silk market trajectory. The silk market boomed in 1886, slumped in 1895 and boomed again in the period beginning from 1899 [19].

Despite Gunma Prefecture's head start in raw silk production, boasting the government-established Tomioka Filature Plant since 1872, Nagano quickly caught up to become the number one raw silk producing region in Japan. Nagano Prefecture ${ }^{2}$ and its neighboring prefecture, Gunma, together produced the largest share of raw silk (Figure 3, data taken from [19] based on the six surveys of the raw silk industry by Ministry of Agriculture and Trade [23]).

2 The modern Prefecture of Nagano was established by the Meiji government in 1876. 
Figure 3. Raw Silk Production in Japan by Prefecture, 1891-1911.

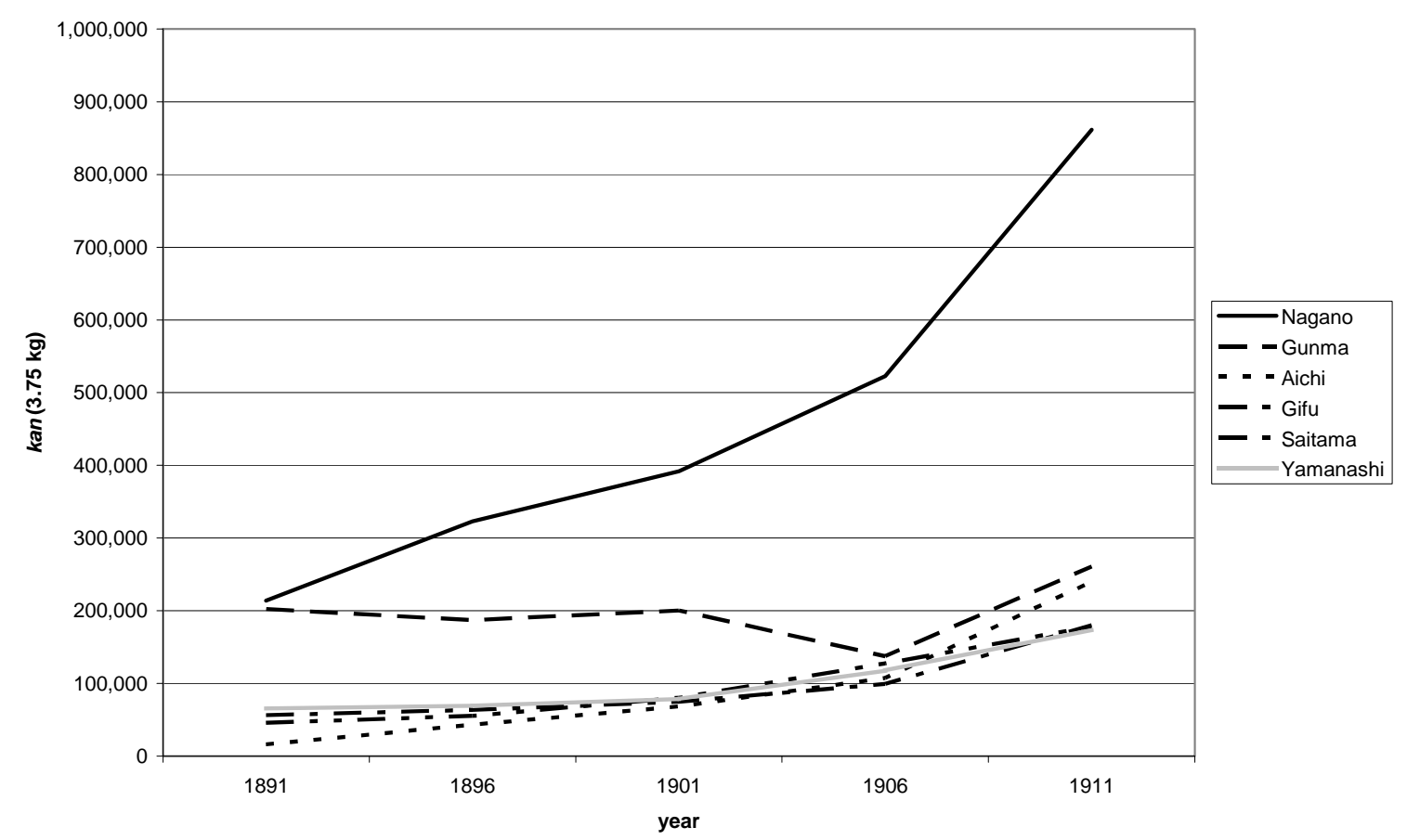

Compared with Nagano and Gunma, all the other prefectures' contributions to Japan's raw silk production were of a much smaller amount. Since 1896, the increase in raw silk production in Nagano put the region as the paramount leader in supplying raw silk for Japan's export. This increase can at least be in part attributed to the initiative taken by Suwa, Nagano, in successfully developing a modern silk-reeling factory industry [24]. Being the number one producer of raw silk in the number one supplier country meant high demand for a large labor force with the dexterity to work in the raw silk industry, thereby having inevitable consequences on Japan's female population, the topic of the next section.

\section{Nagano's Female Workers in the Raw Silk Industry}

This section reviews the female workers' situation, which has been well discussed in other sources (e.g., [7]). Although the Meiji government encouraged silk production by setting the Tomioka Filature Plant as a model ${ }^{3}$, it was not the first plant producing raw silk. Two private plants using Italian machines were established in 1870. In Nagano, as well as in other major raw silk producing regions, private filature plants unrestricted by government regulations mushroomed in the ensuing decades. Because private plants were not controlled by the government, it is difficult to know exactly how many women worked in those plants. However, we can indirectly derive some estimates. By 1879, there were 665 mechanical silk-reeling plants in Japan, 358 of which were located in Nagano [7]. In 1921, there were 623 filature plants in Nagano Prefecture [25]. The size of the plants varied greatly, and a twenty thousand total workforce would not be an overestimate, because just 203 silk mills in Nagano in 1903 already employed a total number of 13,620 workers (12,519 females and 1,101 males) [15]. In 1896, Japan had 593,809 female workers and 32,500 male workers in the raw silk industry [25]. In the

3 Having been operated by the government in the red for many years, the Tomioka Filature Plant was sold to the Mitsui-family in 1893. 
same year, Nagano produced 323,039 kan (approximately $3.75 \mathrm{~kg}$ in a kan) of raw silk, and the national total production was $1,442,720$ kan [19]. This puts Nagano at $22.4 \%$ of the national total. Assuming that it on average would require the same proportion of workforce for producing that amount of silk, while acknowledging the variation in productivity, the estimation gives 133 thousand of the female workers to Nagano's raw silk industry in 1896. This estimate describes a sizable female labor force and is significantly higher than the official figures of 33 thousands in 1900 or 56 thousands in 1911, reported in [7].

The female workers were mostly girls of a tender age, when their eyesight was sharp and their fingers were nimble. They often were hired under contract by the plants and were forbidden to return home during the contract period. Their lives were strictly governed by the work schedule of the plants. Here is a sample of a typical work schedule (adjusted according to the calendar on a half-month basis) for the first half month of March and October in one such plant in Hirano Village, Nagano Prefecture, in 1900 [25]:

$\begin{array}{ll}\text { Rise: } & \text { 5:15 AM } \\ \text { Work: } & \text { 5:40 AM } \\ \text { Breakfast: } & \text { 7:00 AM } \\ \text { Work: } & 7: 15 \mathrm{AM} \\ \text { Lunch: } & 11: 30 \mathrm{AM} \\ \text { Work: } & 11: 45 \mathrm{AM} \\ \text { Supper: } & 5: 00 \mathrm{PM} \\ \text { Work: } & 5: 20 \mathrm{PM} \\ \text { End of Work: } & 9: 00 \mathrm{PM} \\ \text { Bath until: } & 10: 30 \mathrm{PM}\end{array}$

The work schedule amounts to a workday of 14 and $1 / 2$ hours. Work schedules for other half-month periods varied from 12 and 1/3 hours for the second half of March and September to another 14 and $1 / 2$ workday for the second half of February and October. Work schedules for other months fell between 12 and $1 / 3$ hours and 14 and $1 / 2$ hours. There were obvious seasonal variations in the length of working hours $[15,24]$. Nevertheless, the work schedules themselves speak volumes about the female workers' hard life at the plant.

To make life more bearable under the watchful eye of foremen in the confined plants, toiling away at the filature machine, women workers composed songs to sing along while reeling. The songs provide valuable testimonials to the kind of lives they led. The lyrics to one such song are given below [26],

"At age twelve I began to learn to reel,

Instead of reeling finer silk,

My body has gotten thinner."

While the song above is about how the worker herself related to the job, the following song expresses workers' feelings toward the factory and the working conditions [7],

"At other companies, there are Buddhas and Gods.

At mine, only demons and serpents.

When I hear the manager talking, 
His words say only 'money, money and time.'

The demon overseer, the devil accountant,

The good-for-nothing chrysalis.

If you look through the factory's regulations,

You see that not one in a thousand lies is unused.

We have to follow the regulations.

We have to look at the foreman's nasty face."

The lyrics of another song compare life at the plant to life in prison ([25], p. 375),

"Doing duty in this plant is doing time in prison,

The absence of a metal chain is the only difference;

Harder than a bird in a cage or life in prison,

Is our residence in these barracks;

The plant is hell and the foreman is devil,

Spinning and turning is the spool of fire ${ }^{4}$.

The year's contract and the advance money,

Bound our feet to no end."

These verses give a vivid description of the female workers' feelings toward their plant, their foremen and the lives they were living. They represent thousands of such songs and verses from the mouths of Meiji silk mill women and provide vital historical records of the history that was denied of these women [27]. The songs they sang wove a sad story told over and over again to the never-ending tunes of the filature machines and are given here to describe the female workers' lives. The factory regulations also embodied a gendered hierarchy in the workplace, similar to that found in Malaysia in the 1970s by Ong [4]. From this, we see that the diffusion of Western gendered institutional structure occurred almost instantaneously, as economic globalization started and worked in concert with traditional Confucian ideology that had been dominant prior to and during the Meiji Restoration.

The songs above describe an important aspect of the workers' lives. On the other hand, these female workers must also have had mixed feelings about factory work, judging from interviews conducted by Yamamoto [25] of 580 surviving members of Nagano silk reelers: $90 \%$ of them thought the meals were delicious, $10 \%$ thought they were average, no one thought they were poor; $22 \%$ considered work in the plants enjoyable, $75 \%$ had neutral feelings toward it and 3\% regarded it as hard; $70 \%$ thought the pay was high, $30 \%$ thought it was average and no one thought it was low. We may want to be careful with interpreting these results, because there might be a selection bias in interviewing the surviving female workers. Those who felt they were prisoners of the factories may not have survived to the time of the interviews, let alone those who committed suicide in the plants to avoid harassment, shame, maltreatment and hardship.

Taken together, these songs reflect the gendered hierarchy in the silk reeling plants. Foremen as well as proprietors represented the sex that held the structural power in society, while female workers were the traditionally powerless and oppressed sex. Even though in a patriarchal society, such as

4 In Japanese, "the wheel of fire" or "the spool of fire" means "being hard up." The phrase is used as a pun here. 
Japan, gender inequality had been commonplace, it occurred mainly in the family in forms that would appear to be much more bearable when a wife obeyed a husband or a daughter a father. Regardless of the type of gender inequality, at home, there was at least a common goal of survival and family wellbeing shared by different members of the household. In a factory setting, however, the severity of gender inequality was unprecedented and took place on a collective scale and often could take the form of open harassment, sexual or otherwise, perpetrated by strangers. Without the familial protection and without pretence, an institutionalized gendered hierarchy became a by-product of the silk reeling machinery. With the raw silk destined for the domestic and overseas markets, the women workers were destined for the bottom-rung of the social hierarchy at the plant.

The hardworking hours spent by these Nagano women in front of the filature machines, throwing threads and reeling silk, were the building blocks of Japan's raw silk industry and contributed to the nation's export and its part in global trade. Considering the importance of Japan's raw silk industry in its overall trade with the world, it must be apparent that Japanese women paved the foundation of the Empire's development of capitalism, while at the same time being subject to harsh working conditions.

\section{Population Growth during the Meiji Era}

An examination of the population growth in the nation and in Nagano, combined with the area's relative lack of resources, will assist us in understanding the context in which Nagano became the raw silk center of Japan and many young women became silk reelers. Japan's population had been growing when the Meiji Restoration began in 1868. During the Tokugawa period (1600-1868), the population of Japan almost doubled from an estimated 18 million to about 35 million, accompanied by rapid urbanization, chiefly in Edo (today's Tokyo) [28]. ${ }^{5}$ This trend of population increase continued with a faster pace in the Meiji period. From the beginning of Meiji to the start of World War II, Japan's population again doubled from around 35 million to about 70 million. Constructed from population statistics [29,30], Figure 4 shows the population trends in both Japan and Nagano.

The data for Japan cover most of the Meiji period from 1872 to 1904, while the data for Nagano cover the period of 1884 to 1904 . With more than one million people in 1884, Nagano constituted an important portion of Japan's population. The increase in Nagano's population over the period almost paralleled Japan's population increase. The population increases in the nation and in the prefecture appear to be constant and continuous. Population growth can reflect accompanying increases in the number of households and the size of the households. ${ }^{6}$ Therefore, it is necessary to examine fertility trends during this period of population growth. However, a high fertility rate accompanied by a high mortality rate would result in little growth. This suggests we should view both fertility and mortality trends in the period (Figure 5). ${ }^{7}$

\footnotetext{
Systematic national population statistics date back to 1721 [28].

6 For example, mirroring population growth, the number of households in a village in northeastern Japan increased 1.5-times, and the mean household size also rose from five to six between 1760 and 1870 [31].

7 These vital rates are computed using data from the available years of the Statistical Annual of the Japanese Empire (Statistical Bureau of the Cabinet 1890-1906) and the Statistical Summary of the Japanese Empire (Statistical Bureau of the Cabinet 1895-1908). CBR are computed by dividing the number of live birth reported for a given year into the midyear population, and CDR are computed by dividing the number of deaths reported for a given year into the midyear population. Population statistics were gathered for most of the Meiji years for January 1 up to 1886, and they were
} 
Figure 4. Population Trends during the Meiji Era.

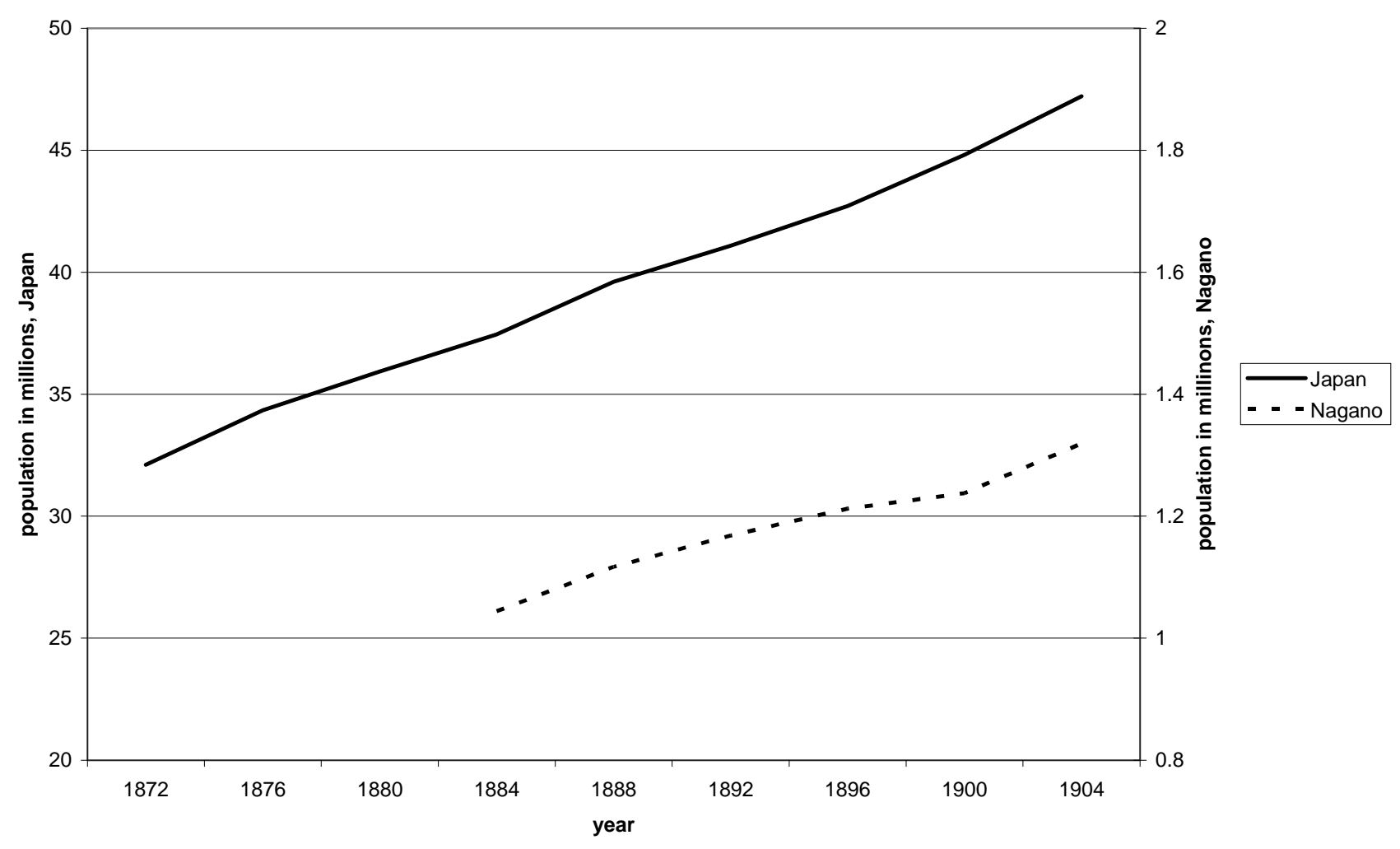

Figure 5. Demographic Forces in the Meiji Era.

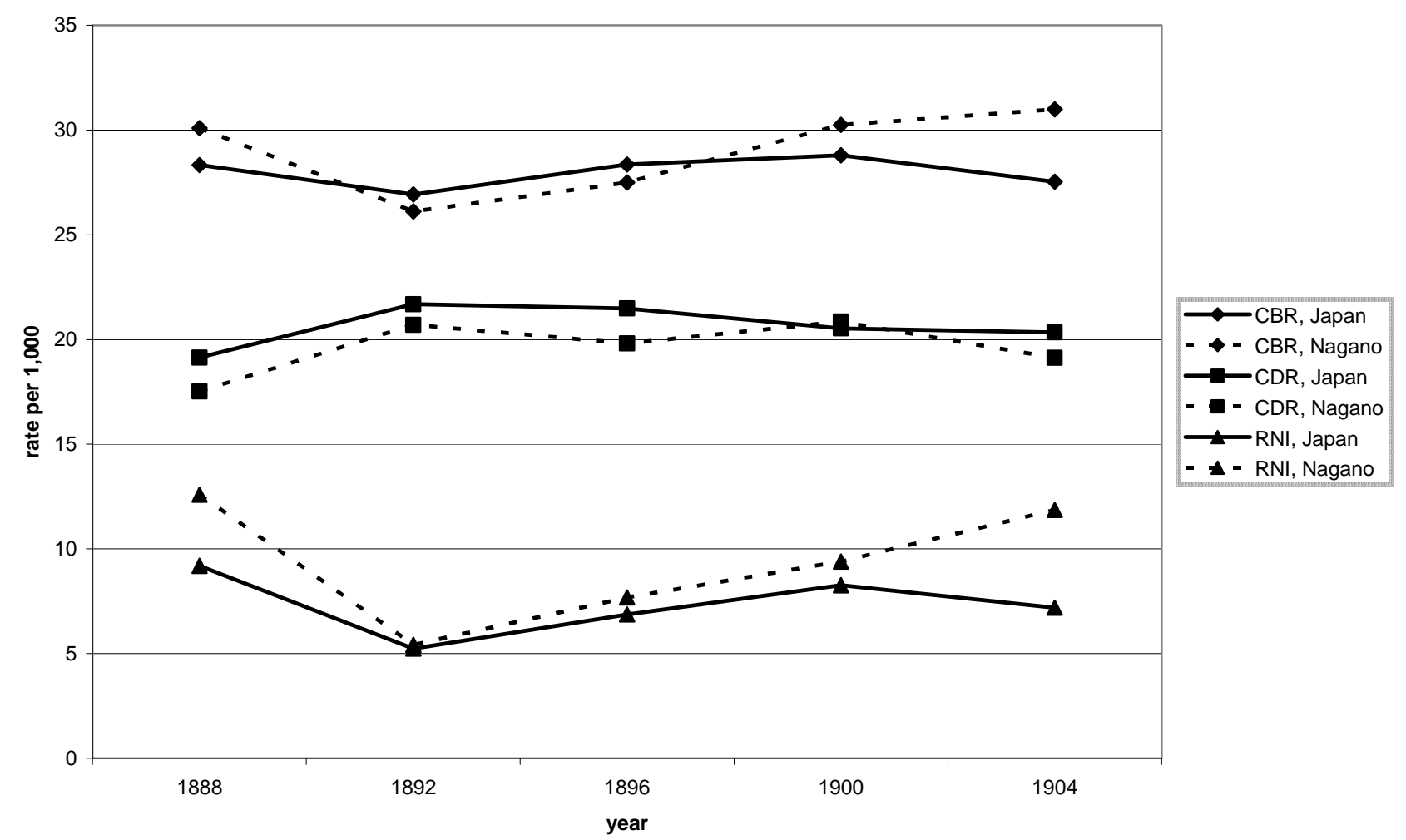

gathered for December 31 starting from 1886. Thus, midyear populations are estimated by linear extrapolation, a reasonable approach given the linear trend of population increase shown in Figure 1. 
Japan's crude birth rates (CBR) hovered around 27 to 28 per thousand, while Nagano's was 26 to 30 , for much of the period above Japan's. For the same period, Japan's crude death rates (CDR) were between 19 and 22 per thousand and Nagano's between 17.5 and 21 per thousand, below Japan's for almost the entire period. The difference between CBR and CDR gives the rate of natural increase (RNI). Japan's RNI during the period was approximately between five and 11 per thousand population, while Nagano's was approximately between 5.5 to 12.6 per thousand, always above Japan's. It is clear that Nagano's population growth, or population pressure, was higher than the nation's, which was already high.

Population growth may have been essential in paving the ground for capitalism. However, too much population pressure may impede capitalist growth instead. Because, in Meiji Japan, the growth potential in agriculture was limited, the Meiji government spearheaded the raw silk industry as a major step in Japan's industrialization after Japan had emerged from a "locked country," or closed nation, to welcome Western technology and know-how. This shift in emphasis from traditional agriculture to modern industry required a move of the labor force from the farm fields to the plants. Since the raw silk industry in Nagano was the one that demanded a lot of laborers - not brawny laborers, but ones with great dexterity and able to learn new skills — naturally, young women became ideal labor force candidates. However, a note of caution is necessary here. Laying out the population conditions does not mean population growth caused the silk-reeling industry to develop in Nagano. It just provided one of the necessary conditions for the silk industry. Indeed, the location of developing a silk-reeling industry in Nagano was not a coincidence. The Suwa region had been a center of hand reeling for a long time. In addition, the three production groups - the large machine reeling mills, the small machine reeling mills and hand reelers - coexisted in the region in Meiji Japan [17]. Cooperative hand reeling was introduced in 1884 [24], though further technological innovation in 1907 allowed large plants to re-reel hand-reeled raw silk, so that the traditional production was able to be firmly integrated in the industry [17]. In addition, there was a fair amount of labor migration, at least in the post-Meiji, years such that Nagano's silk industry drew labor from the neighboring prefectures of Gunma, Niigata and Yamanashi [15].

\section{The Natural Resources of Nagano in Meiji Japan}

"In the territory of the Nation of Shinano

Ten provinces join together

Towering mountains stand tall

Running rivers flow far

Matsumoto, Ina, Saku, Zenkouji

Are four fertile plains

Ocean is not a possession

But we have the cornucopia of all things

The Valley of Kiso teeming with cedar and cypress

The Lake of Suwa abundant with fish

The people's earnings are high

And the grains give bounty harvest 
Not to mention the mulberry trees that

Established the silkworm raising business

The fine silk, albeit its lightness

Ties to the destiny of the nation"

Perhaps no words other than these from the two verses (out of the six) of the prefectural anthem of Nagano can better portray the great resources of the region and the importance of the silk industry (author's translation based on Nagano Prefectural Government [32]). The lyrics were written by Kiyoshi Asai in 1899, with music composed by Sueharu Kitamura in 1900, when the raw silk industry was in its heyday.

When Nagano had begun building foreign relations, it introduced silk-reeling machines and devoted its energy to developing silkworm-raising techniques. With the success of Nagano's raw silk industry, Nagano became the "Silk Kingdom" of Japan. Its modern history is so closely tied to the rise and fall of the silkworm-raising and silk-reeling industries that the history of the raw silk industry could be said to be the history of Nagano itself [33].

Its natural beauty and rich resources praised in the prefectural anthem notwithstanding, the potential of Nagano's land for agriculture may not be as immense as it seems. According to the information reported in 1890 by Statistical Bureau of the Cabinet of Japan, Nagano had 5,084.3 square miles in 1888. Some of the land was government-owned for purposes, such as office buildings, temples and shrines. Of the land for private ownership, a comparison of the percentage of Nagano's farmland with that of Japan and Chiba, another East Japan prefecture on that other side of Tokyo that has been better known for farming, may shed light on the extent and limitations of Nagano's agricultural resources (Figure 6). Chiba is an arbitrary choice to avoid going into a full-scale comparison of all prefectures. Both were agricultural and both had a similar level of traditional commerce in terms of the percent of people operating retail sales in the mid-Meiji period (1905), according to Matsumoto's Table 2.3 [34]. However, unlike Nagago, Chiba is a coastal prefecture with distinctly different topographical and environmental features from Nagano's, our point of focus here. Also, it was just far enough without being a labor migration prefecture of origin.

Of the privately-owned land in Nagano in 1888 , about $12 \%$ was paddy field and $15.5 \%$ was (dry) farmland for other crops. The same figures were about $20 \%$ and $16.5 \%$ for the national average and about $30.5 \%$ and $21 \%$ for Chiba, respectively. While Nagano boasted more forested area than Chiba, the amount was far below Japan's, with its vast forests in the north. What is most striking is Nagano's wasteland proportion, which occupied $30 \%$ of the total private land in 1888 . In contrast, wasteland constituted only about $6.6 \%$ in Chiba and $7.5 \%$ in Japan in the same year. The wasteland in Nagano was typically hilly terrain with little forestation and was difficult, though not entirely impossible, for reclamation for agricultural purposes. Hundreds of years of farming very much established the boundaries of cultivable land, and the proportions of farmland (as compared with the other types of land) would change very little over time (Figure 7).

In 1906, six years before the end of the Meiji Era, Nagano's paddy field and (dry) farmland proportions increased slightly, with about a percentage point reduction in forested area and a slight increase in the proportion of wasteland. The changes in these land categories between the two dates in either Chiba or Japan as a nation were rather moderate, as well. It should be safe to say that the area of arable land in Nagano stayed very much unchanged throughout the Meiji period. 
Figure 6. Private Land Usage in Nagano, Chiba and Japan, 1888.

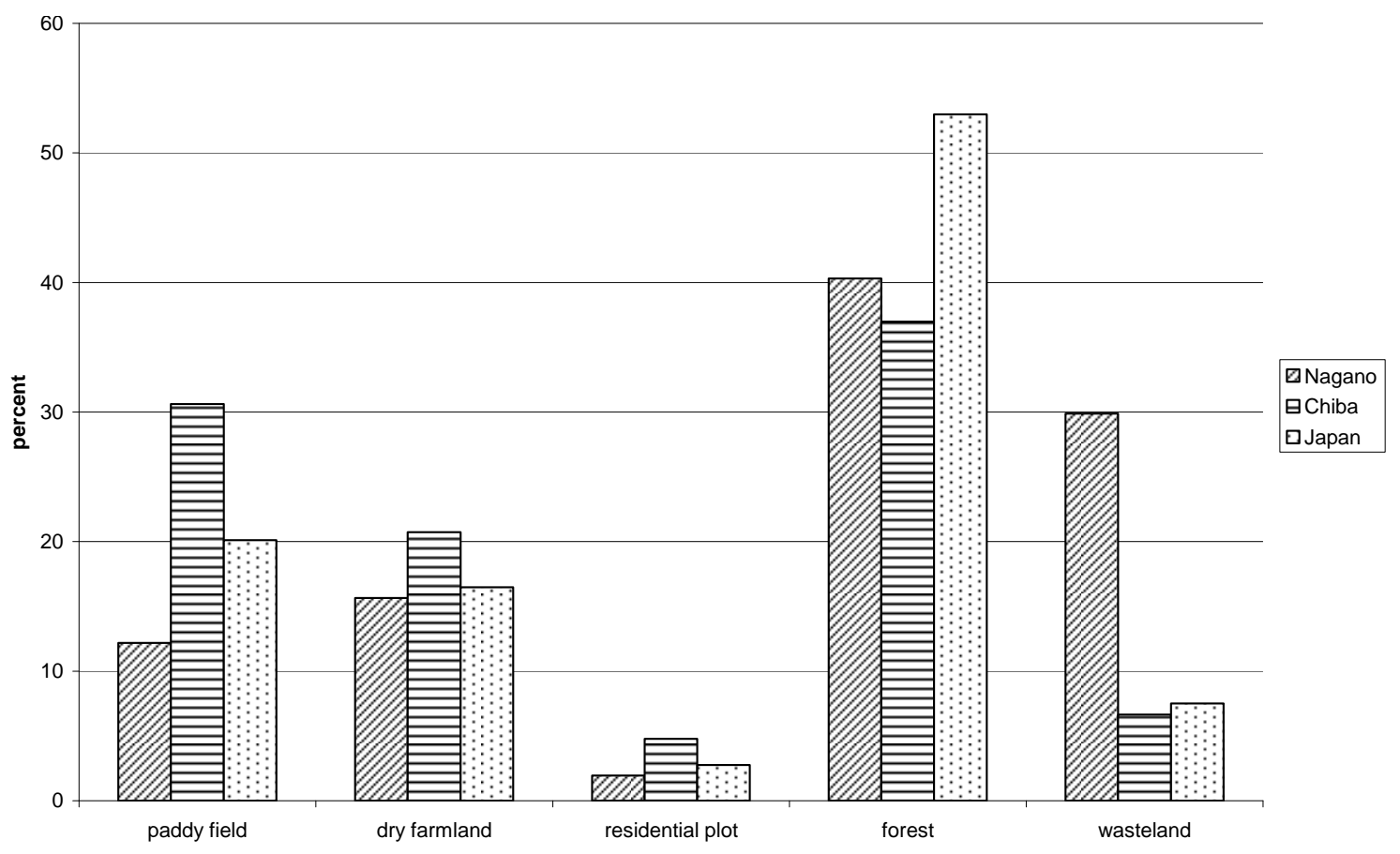

Figure 7. Private Land Usage in Nagano, Chiba and Japan, 1906.

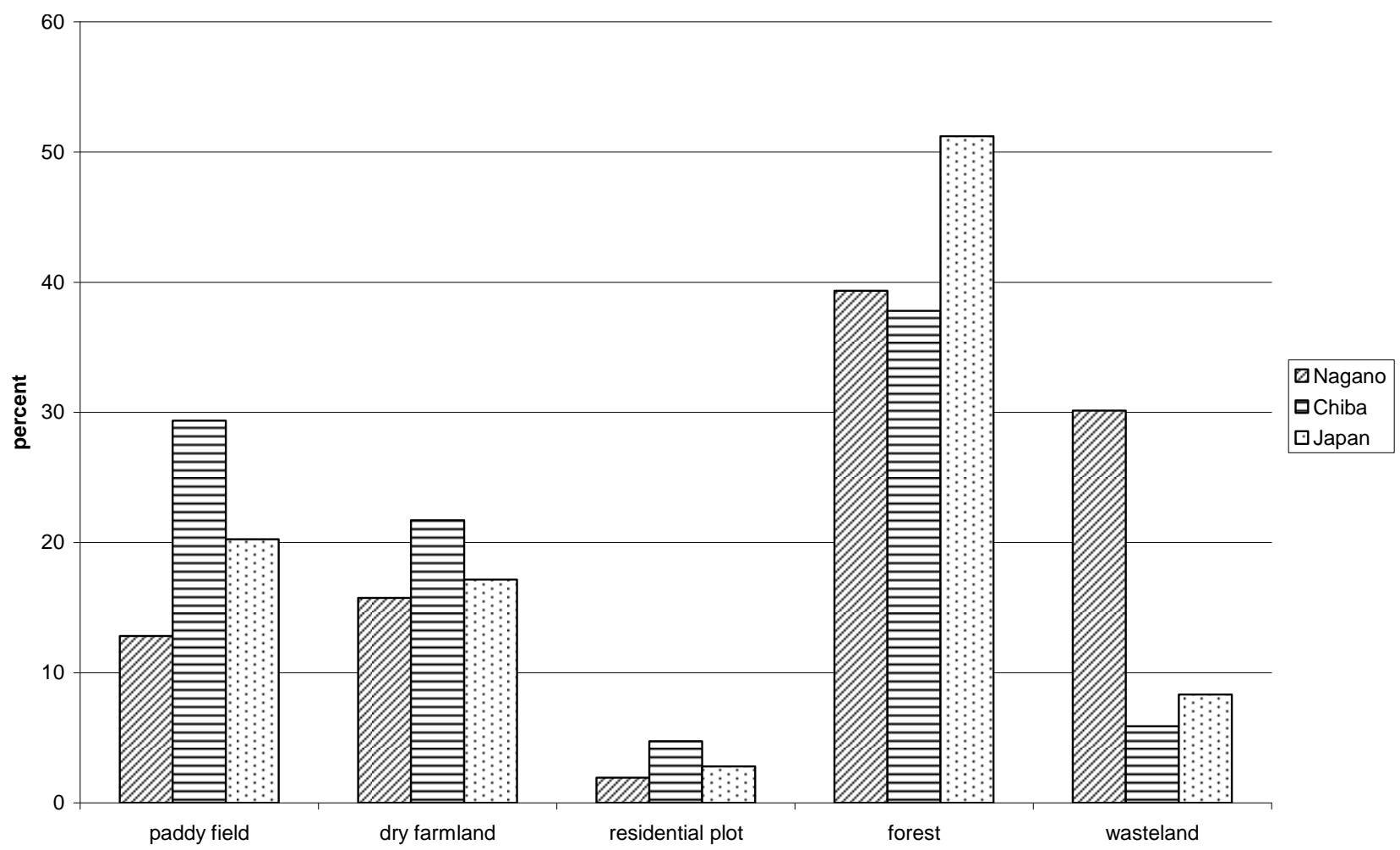

With the population pressure produced by the higher RNI in Nagano, but lesser amount of natural resources, Naganoans need to find a way to move ahead, as poverty and insufficient food supply were common household stories. Mulberry trees, on whose leaves silkworms were raised, could tolerate just about any soil type, as they had initially been planted in Japan to curtail soil erosion and proved to be hardy. Silkworm raising and silk reeling using the sedentary method had been a tradition in the 
Nagano region for a long time. Thus, establishing a strong raw silk industry using the filature method introduced from the West became a natural response to the population pressure accompanied by limited resources.

Thousands upon thousands of young women were hired and contracted into the silk reeling factories during the Meiji period, not purely because of their perceived nimble fingers and capacity to endure hardship. Many of these women's families, sometimes some of the women themselves, had financial considerations on their mind. According to Statistical Bureau of the Cabinet's 1895 summary report, in the area of central Honshu (which includes central Japan) outside the District of Tokyo in 1888, a male farmer earned 0.19 yen per month; a female farmer, 0.12 yen; a male silkworm farmer, 0.22 yen; a female silkworm farmer, 0.16 yen; and a female silk reeler, 0.19 yen. Working in any part of the silk making process would bring home higher income for either sex than farm work. For women, the job of a silk reeler would guarantee them the equal amount of pay to a male farmer. Faced with the local reality of poverty and possible hunger in the villages, the higher pay and guaranteed meals would be attractive to many villagers. That may explain, at least in part, after considering selection bias, the positive responses by many women interviewed by Yamamoto [25] about life in the plants. At the same time, the pay scale of women and men reelers also further reveals gender inequality in the raw silk industry, despite the commonly believed dexterity of the female reelers. Faced with the gender inequality in wage anywhere, many women chose to leave home and work in the raw silk industry to increase their earning potentials for their families, in spite of their difficult lives at the plants as discussed earlier. This trend, at least in part, was due to the opportunity offered by the rank-order wage system, initially introduced in the 1880s in Nagano, which served to encourage productivity (and quality) by raising the incentive of workers without increasing the total sum of wages [35]. The system favored younger, more dexterous workers.

\section{Global Processes and Local Realities}

Social theorists, particular those studying dependency in the world and regional systems, have long established how local regions are integrated in the larger system in which the local areas are dependent parts. During the process of the global integrating the local, women are often marginalized, particularly in the areas where patriarchy has been the tradition. Here, we consider the concept of glocalization, a concept that no longer ignores the importance of the local, whereas much of the talk about globalization assumes globalization is a process that overrides locality [36].

In this paper, we have examined the process through which one local area in Japan was integrated into the global raw silk production and trade in the late 19th and early 20th centuries. Clearly, it is not simply the convenience of having some silk reeling tradition that made Nagano the "Silk Kingdom" of Japan. Both Nagano's tradition in hand-reeling silk production as well as its population pressure and its agricultural resources relative to the others' must be taken in account in viewing the rise of its raw silk industry, despite its lack of a port for easy import and export. These local conditions, once the national initiation had been made to launch the raw silk production drive, interacted directly with the global trade market. In a patriarchal agricultural society where men tended to dominate labor, the pressure of population increase, the squeeze of the agricultural environment and the tradition of silk making collaborated to produce an overwhelmingly female labor force in Nagano's raw silk industry. 
Therefore, the pressures and squeezes as well as the favorable conditions of every locale contribute to the working of the globalization and glocalization process. From the discussions above, we may conclude the following: the impact of the local on the global in terms of contributing its resources and labor, brought about and constrained by its pressures and squeezes and encouraged by favorable local conditions, is as great as the impact of the global on the local in terms of integrating it into the larger process. Just as Chase-Dunn [13] noted, in the process of globalization, economic competitiveness is now only meaningful in the global context, rather than the national or local context, as prior to the initiation of globalization. The local realities in Nagano assisted its integration into the global economic enterprise.

However, economic competitiveness comes at a price. Intertwined with economic globalization is political globalization that carries with it an institutionalized gendered hierarchy. Formalized by factory rules and enforced by the foreman's ruthless hand, the gendered hierarchy found in the silk factories was much more polarized between the sexes. In the case of Nagano, the interaction between its raw silk industry and global trade not only rendered the prefecture a prime location in Japan's modernization process, but more importantly, also made its women better known for their deeds in the process. They were better known for their marginalization as well as for their contributions and exploits. These were the results of glocalization. As Bauman [14] insightfully noted, glocalization means the reallocation of poverty and stigma from above. It means a reallocated order of gender inequality, with women being subjected to marginalization on a global scale. The women in the raw silk industry of Nagano contributed dearly to the history of Nagano, as the prefectural anthem partially recognized (only the importance of silk, not that of their women) and indeed helped write the history of modern Japan and its development.

\section{Acknowledgments}

The author would like to thank Amrita Basu, Hiroko Tanaka and the two anonymous reviewers for comments on earlier versions of the paper.

\section{References}

1. Lourdes Beneria, and Gita Sen. “Accumulation, Reproduction and Women's Role in Economic Development: Theoretical and Practical Implications.” Feminist Studies 8 (1981): 157-76.

2. Ester Boserup. Women's Role in Economic Development. New York: St. Martin, 1970.

3. Diane Elson, and Ruth Pearson. 'Nimble Fingers Make Cheap Workers: An Analysis of Women's Employment in Third World Export Manufacturing." Feminist Review 7 (1981): 87-107.

4. Aihwa Ong. Spirits of Resistance and Capitalist Discipline: Factory Women in Malasia. Albany: State University of New York Press, 1987.

5. Kathryn Ward. "Women in the Global Economy." In Women and Work. Edited by Barbara Gutek, Ann H. Stromberg, Laurie Larwood. Newbury Park: Sage, 1988, 17-48.

6. International Sericultural Commission. "Raw silk production (tonnes)." Available online: http://www.inserco.org/uk/stats.php\#RAWSILKPROD (accessed on 28 November 2012).

7. E. Patricia Tsurumi. Factory Girls: Women in the Thread Mills of Meiji Japan. Princeton: Princeton University Press, 1990. 
8. Gail L. Bernstein. "Women in the Silk Reeling Industry in Nineteenth Century Japan." In Japan and the World. Edited by Gail L. Bernstein, and Haruhiro Fukui. New York: St. Martin's Press, 1988, 54-77.

9. Kanji Ishii. Nihon Sanshi-gyo Shi Bunseki (Analysis of Japanese Silk Industry). Tokyo: Tokyo Daigaku Shuppankai, 1972.

10. Satoru Nakamura. "The Development of Rural Industry." In Tokugawa Japan. Edited by Chie Nakane and Shinzaburō Ōishi. Tokyo: University of Tokyo Press, 1990, 81-96.

11. Masanori Nakamura, eds. Technology Change and Female Labour in Japan. Tokyo: United Nations University Press, 1994.

12. Kären Wigen. The Making of a Japanese Periphery, 1750-1920. Berkeley: University of California Press, 1995.

13. Christopher Chase-Dunn. "Globalization: A World-Systems Perspective.” Journal of World-Systems Research 2 (1999): 187-215.

14. Zygmunt Bauman. "On Glocalization: Or Globalization for Some, Localization for Some Others." Thesis Eleven 54 (1998): 37-49.

15. Janet Hunter. Women and the Labour Market in Japan's Industrialising Economy. London: Routledge, 2003.

16. Masayuki Tanimoto. "The Role of Tradition in Japan's Industrialization: Another Path to Industrialization." In The Role of Tradition in Japan's Industrialization. Edited by Masayuki Tanimoto. Oxford: Oxford University Press, 2006, 3-44.

17. Satoshi Matsumura. "Dualism in the Silk-reeling Industry in Suwa from the 1910s to the 1930s." In The Role of Tradition in Japan's Industrialization. Edited by Masayuki Tanimoto. Oxford: Oxford University Press, 2006, 93-120.

18. Jun Suzuki. “The Humble Origins of Modern Japan's Machine Industry.” In The Role of Tradition in Japan's Industrialization. Edited by Masayuki Tanimoto. Oxford: Oxford University Press, 2006, 140-56.

19. Ken Togo. "Elements of the development of the Japanese raw silk industry: An explanation by the NK model." FASID-IDRI Occasional Paper Series, International Development Research Institute, the Foundation for Advanced Studies on International Development, Japan, 1997.

20. Ryo Kambayashi. "The Registration System of the Grade Wage: From Cooperation to a Market for Human Capital? A Lesson from the Japanese Silk Reeling Industry." In Production Organizations in Japanese Economic Development. Edited by Tetsuji Okazaki. London: Routledge, 2007, 39-74.

21. Ministry of Agriculture and Forestry. Sanshi-Gyou Youran (Handbook on Silk Industry). Tokyo: Ministry of Agriculture and Forestry, 1937.

22. Christopher Chase-Dunn, Yukio Kawano, and Benjamin D. Brewer. "Trade Globalization since 1795: Waves of Integration in the World-System.” American Sociological Review 65 (2000): 77-95.

23. Ministry of Agriculture and Trade. Daiichi-Ji (Daini-Ji, Daisan-Ji, Daiyon-Ji, Dairoku-Ji, Dainana-Ji) Zenkoku Seishi-Koujyou Chousa-Hyou (The First [Second, Third, Fourth, Sixth, Seventh] Survey of Raw Silk Factories in Japan). Tokyo: Ministry of Agriculture and Trade, 1895 (1898, 1902, 1907, 1912, 1916). 
24. Masaki Nakabayashi. "The Rise of a Factory Industry: Silk Reeling in Suwa District." In The Role of Tradition in Japan's Industrialization. Edited by Masayuki Tanimoto. Oxford: Oxford University Press, 2006, 183-216.

25. Shigemi Yamamoto. Aa Nomugi Toge: Aru Seishi Koujyo Aishi (Ah Nomugi Pass: The Tragic History of Raw Silk Female Workers). Tokyo: Asahi Shimbunsha, 1972.

26. Tsuyoshi Kawada, Yamashika Seiji, and Bitou Masahide. Atarashii Shakai-Rekishi (New Social Studies-History). Tokyo: Tokyo Shoseki, 1987. Ministry of Education approved textbook.

27. E. Patricia Tsurumi. "Yet to Be Heard: The Voices of Meiji Factory Women." Bulletin of Concerned Asian Scholars 26 (1994): 18-27.

28. Susan B. Hanley. "Population Trends and Economic Development in Tokugawa Japan: The Case of Bizen Province in Okayama." Dredlus 97 (1968): 622-35.

29. Statistical Bureau of the Cabinet. Nippon Teikoku Toukei Nenkan (Statistical Annual of the Japanese Empire). Tokyo: Statistical Bureau of the Cabinet, 1890-1906.

30. Statistical Bureau of the Cabinet. Résumé Statistique de l'Empire du Japon (Statistical Summary of the Japanese Empire). Tokyo: Statistical Bureau of the Cabinet, 1895-1908.

31. Futoshi Kinoshita. "Household Size, Household Structure, and Developmental Cucle of a Japanese Village: Eighteenth to Nineteenth Centuries.” Journal of Family History 20 (1995): 239-60.

32. Nagano Prefectural Government. "Prefectural Song 'Shinano no Kuni' (The Nation of Shinano)." Avaiable online: http://www.pref.nagano.lg.jp/gaikokugo/prefectural/song.htm (accessed on 28 November 2012).

33. Nagano Prefectural Government. "History: Recent Times-Industrial Development and the Modern State.” Avaiable online: http://www.pref.nagano.lg.jp/gaikokugo/prefectural/h-gendai.htm (accessed on 28 November 2012).

34. Takanori Matsumoto. "The Development of Traditional Industries in Modern Japan: A Statistical Exposition.” In The Role of Tradition in Japan's Industrialization. Edited by Masayuki Tanimoto. Oxford: Oxford University Press, 2006, 45-71.

35. Masaki Nakabayashi. "Toukyu Chinginsei no Kakuritsu: Suwa Seishigyou ni okeru Yuuintaikei (The Establishment of the Rank-Order Wage System: the Incentive System of the Suwa-District Silk Reeling Industry).” Shakai Keizai Shigaku (Socio-Economic History) 64 (1998): 58-70.

36. Roland Robertson. "Glocalization: Time-Space and Homogeneity-Heterogeneity." In Global Modernities. Edited by Mike Featherstone, Scott Lash, Roland Robertson. Thousand Oaks: Sage, 1995, 25-44.

(C) 2013 by the author; licensee MDPI, Basel, Switzerland. This article is an open access article distributed under the terms and conditions of the Creative Commons Attribution license (http://creativecommons.org/licenses/by/3.0/). 